dr inż. Marek Sobaś

Instytut Pojazdów Szynowych „TABOR”

\title{
Kryteria obiektywnej oceny prognozwanych stanów osi zestawów kołowych pojazdów trakcyjnych
}

\begin{abstract}
$W$ artykule przedstawiono kryteria obiektywnej oceny prognozowanych stanów osi zestawów kołowych trakcyjnych oraz tocznych. Jednym z kryteriów jest obserwacja propagacji pęknięcia w ustalonych okresach kontrolnych. Przedstawiono rolę badań ultradźwiękowych $w$ całej metodyce prognozowania stanu osi zestawu kołowego. Przedstawiono stanowisko, dotyczqce ograniczenia wieku eksploatacji osi zestawów kołowych jako środka zwiększajacego niezawodność i bezpieczeństwo. Artykut zostat opracowany $w$ ramach projektu badawczo-rozwojowego $\mathrm{Nr} R$ 10 004806/2009 pt. „, Mikroprocesorowy system diagnostyczny głównych systemów trakcyjnego pojazdu szynowego uwzględniajacy ocenę bieżaca i prognozowanie stanów", finansowanego z budżetu Ministerstwa Nauki i Szkolnictwa Wyższego.
\end{abstract}

\section{Wstęp}

Oś zestawu kołowego jest jednym z newralgicznych elementów pojazdu szynowego, decydującym o bezpieczeństwie eksploatacyjnym pojazdu szynowego. Osie zestawów kołowych mają 150 letnią historię i są przedmiotem stałego rozwoju konstruktorów, inżynierów zajmujących się obliczeniami wytrzymałościowymi oraz fachowców zajmujących się inżynierią materiałową. Element ten jest uznawany jako najbardziej obciążony w eksploatowanym pojeździe kolejowym. Problematyka wytrzymałości zmęczeniowej osi zestawu kołowego została poruszona $\mathrm{w}$ opracowaniu OR-9666 [13]. Pomimo, że istnieje poważny postęp w zakresie metod obliczeniowych, które są przedstawione w normach europejskich PN-EN 13104:2009 (osie napędne) [10] oraz PN-EN 13103:2009 (osie toczne) [9] oraz znaczący postęp technologiczny wytwarzania osi i ich odbiorów, które sa przedstawione w normie PN-EN 13261:2009 [11] elementy te są narażone na pękniecie zmęczeniowe, co jest niejednokrotnie przyczyną poważnych katastrof kolejowych, powodujących znaczne straty materialne oraz wypadki śmiertelne. Po ostatniej katastrofie kolejowej w Viareggio we Włoszech pojawiają się głosy o ustanowienie maksymalnego wieku osi zestawów kołowych, po upływie którego oś należy wycofać z eksploatacji i złomować. Pogląd ten jest kompletnie błędny i nie jest uzasadniony z technicznego punktu widzenia, gdyż:

- oś jest zaprojektowana na zmęczenie wysokocykliczne, co oznacza że oś może pracować z nieograniczoną wytrzymałością zmęczeniową; jak wynika $\mathrm{z}$ obecnych doświadczeń eksploatacyjnych podczas 30 letniej eksplo- atacji osie mogą być poddawane $10^{9}$ cykli obciążeń

- o faktycznej wytrzymałości osi decyduje jej stan techniczny, a więc „bezwadliwość” w zakresie określonym przez PN-EN 13261:2009 [11]

- oś nowa jest w takim samym stopniu narażona na pęknięcia zmęczeniowe jak oś eksploatowana, co automatycznie podważa sens określania maksymalnego wieku eksploatacji osi.

Jak wykazuje praktyka eksploatacyjna wypadki kolejowe były spowodowane również pęknięciem osi w stanie nowym. Wynika to głównie $\mathrm{z}$ istnienia w każdym materiale defektów struktury krystalicznej jak dyslokacje, które są odpowiedzialne za odkształcenia plastyczne materiałów oraz mikropękniecia i inne nieciagłości materiałów, które są miejscem inicjacji pęknięcia zmęczeniowego. Pęknięcia powstają w materiale już na etapie jego wytwarzania. Miejscami powstawania pęknięć są wszelkie nieciagłości struktury materiałowej. Na tej podstawie można wyciagnąć wniosek, że jednym z ważnych sposobów zapobiegania zniszczenia konstrukcji poprzez pękanie zmęczeniowe jest między innymi jest prawidłowe posługiwanie się metodami badań nieniszczących, których stosowanie pozwala na bezpieczną eksploatację. Skuteczność badań nieniszczących jest związana między innymi na precyzyjnym określeniu okresów kontrolnych osi zestawów kołowych.

2.Ustalenie okresów kontrolnych osi zestawów kołowych na podstawie symulacji komputerowej 


\subsection{Podstawy zagadnienia}

Podstawą do opracowania zagadnienia związanego $\mathrm{z}$ ustaleniem okresów kontrolnych dla metod badań nieniszczących osi zestawów kołowych były poważne szkody, jakie spowodowała katastrofa kolejowa, związana uszkodzeniem osi zestawu kołowego dalekobieżnego zespołu trakcyjnego przystosowanego do wysokich prędkości ICE, która miała miejsce na moście „Hohenzollernbrücke” w Kolonii (9.07.2008) [4]. Zdarzenie to zainspirowało do ustalenia kryteriów dla okresów kontrolnych dla badań osi zestawów kołowych. Jeśli weźmie się pod uwagę czas od początku eksploatacji dla osi nie wykazującej wad, to wówczas żywotność do pojawienia się pęknięcia (rysy) jest zasadniczą częścią całkowitej żywotności osi zestawu kołowego. Ta pierwsza faza eksploatacji osi zestawu kołowego może ulec skróceniu poprzez występowanie małych błędów, które pojawiły się na etapie wytwarzania i nie zostały wykryte lub powstały wskutek uszkodzeń podczas eksploatacji wywołanymi przez korozję lub uderzenia mechaniczne, które przyczyniają się do powstawania pęknięć zmęczeniowych. Jednak takie zjawiska nie mogą być przeszkodą do ustalenia okresów między-naprawczych. Istotny problem techniczny stanowi to, jakie pęknięcia lub rysy (wymiary i ich lokalizacja) moga być pewnie wykryte za pomocą badań nieniszczących.

\subsection{Przyczyny propagacji pęknięć}

Przy pęknięciu zmęczeniowym każdego elementu konstrukcyjnego całkowita wytrzymałość zmęczeniowa składa się z dwóch części:

$\Rightarrow$ żywotności, wynikającej $\mathrm{z}$ inicjacji pęknięcia zmęczeniowego

$\Rightarrow$ żywotności, wynikającej $\mathrm{z}$ propagacji (rozwoju) pęknięcia zmęczeniowego.

Przy okresowo zmiennych obciążeniach osi jako elementu konstrukcyjnego w otoczeniu pęknięcia (rysy) zmęczeniowego powstaje pole naprężeń $\sigma_{\mathrm{y}}(\mathrm{x}, \mathrm{t})$, które może być scharakteryzowane przez czasowo zmienną intensywność naprężeń $\mathrm{K}(\mathrm{t})$, co jest pokazane na rys.1. Cykliczna intensywność zmiany naprężeń $\Delta \mathrm{K}$ jest decydującym parametrem dla propagacji pęknięcia przy obciążeniu zmęczeniowym.
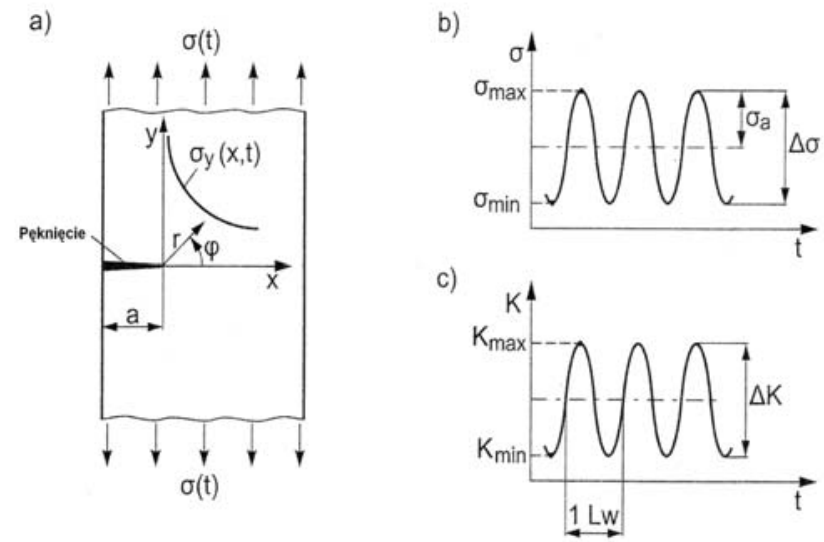

Legenda:

a) część konstrukcyjna z pęknięciem (rysa) o dtugości ,a” przy czasowo zmiennym obciqżeniu, określonej przy pomocy wspótrzędnych biegunowych , $r$ " $i$, , $\varphi$ " na wierzchotku rysy $i$ naprężeniem $\sigma_{y}(x, t) w$ otoczeniu rysy

b) obciażenie części $\sigma(t)$ z amplituda $\sigma_{a}$ względnie $\Delta \sigma$ lub $\sigma_{M A X} i$ $\sigma_{\text {MIN }}$

c) współczynnik intensywności naprężeń $K(t)$ z cyklicznq intensywnościq naprężeń $\Delta K$ jak równiez maksymalnym wspótczynnikiem intensywności $K_{M A X} i$ minimalnym wspótczynnikiem intensywności naprężeń $K_{M I N}$

Rys.1. Związek pomiędzy obciążeniem części i cyklicznym czynnikiem intensywności naprężeń $\Delta \mathrm{K}$

Pomiędzy cykliczną rozpiętością naprężeń $\Delta \sigma$ i aktualną długością pęknięcia (rysy) jak również współczynnikiem geometrycznym $\mathrm{Y}_{\mathrm{a}}$ (a) i współczynnikiem intensywności naprężeń $\Delta \mathrm{K}$ obowiązuje zależność:

$$
\Delta K=\Delta \sigma \cdot \sqrt{\pi \cdot a} \cdot Y(a)=2 \sigma_{a} \sqrt{\pi \cdot a} \cdot Y(a)
$$

Wpływ na propagację pęknięć zmęczeniowych ma również współczynnik asymetrii cyklu R dla obciążeń okresowo zmiennych, który definiuje się zależnością:

$$
R=\frac{\sigma_{\text {MIN }}}{\sigma_{M A X}}
$$

gdzie:

$\sigma_{\text {MIN }}$ - minimalne naprężenia podczas cyklu zmęczeniowego

$\sigma_{\mathrm{MAX}}$ - maksymalne naprężenia podczas cyklu zmęczeniowego.

Przy procesie propagacji pęknięcia zwiększa się długość rysy wraz ze zwiększającą się ilością cykli, przez co zwiększa się również cykliczny współczynnik intensywności naprężeń. Prędkość powstawania pęknięcia (rysy) jest zależna od materiału i musi być ustalona na drodze eksperymentalnej. Wraz ze wzrostem rysy na próbkach normalnych otrzymuje się tzw. krzywą prędkości powstawania rysy, która się zbliża asymptotycznie do dwóch granic, które są przedstawione na rys.2.

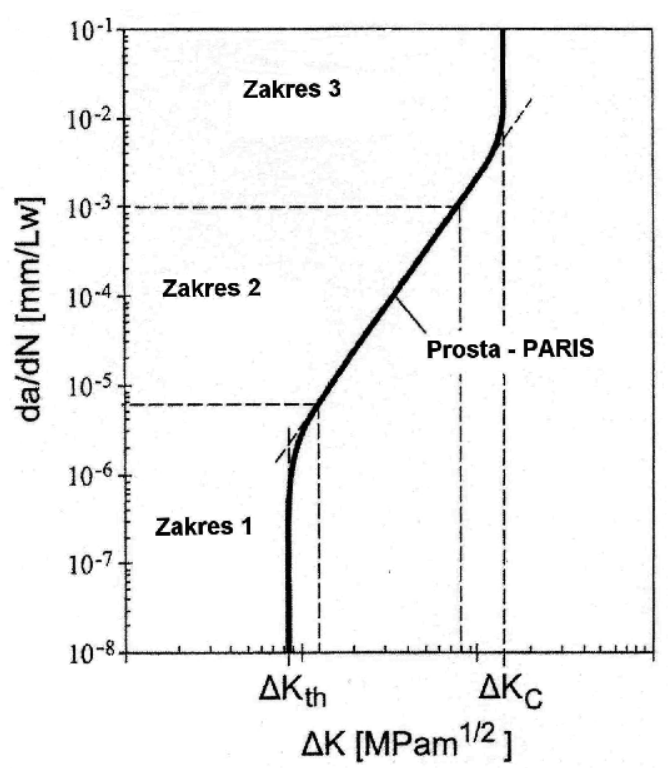


Legenda:

I zakres- matej prędkości pękania od $0 \div 10^{-5} \mathrm{~mm} / \mathrm{cykl}$

II zakres-średniej prędkości pękania od $10^{-5} \div 10^{-3} \mathrm{~mm} / \mathrm{cykl}$

III zakres- dużej prędkości pękania od $10^{-3} \mathrm{~mm} / \mathrm{cykl}$.

Rys.2. Przedstawienie zależności pomiędzy prędkością powstawania pęknięcia i cyklicznym współczynnikiem intensywności naprężeń $\Delta \mathrm{K}$ za pomocą krzywej da/dN

Prędkość propagacji pęknięcia (rysy) można wyznaczyć z zależności:

$$
\frac{d a}{d N}=f(\Delta K)
$$

gdzie:

da - przyrost długości pęknięcia zmęczeniowego dN - przyrost ilości cykli obciążeń zmęczeniowych. Dolna granica wartości pulsującej przedstawia cykliczną intensywność naprężeń $\Delta \mathrm{K}_{\text {th. }}$. Jeśli cykliczna intensywność $\Delta K$ znajduje się poniżej wartości tętniącej to pękniecie (rysa zmęczeniowa), z punktu widzenia klasycznej teorii mechaniki pękania nie jest zdolne do propagacji. Druga granica przedstawia obciążenie pęknięcia, od którego propagacja pęknięcia (rysy) nie jest już stabilna. Warunkiem, który obowiązuje jest to, że $\mathrm{K}_{\mathrm{MAX}}$ osiagnie wartość $\mathrm{K}_{\mathrm{C}}$ względnie:

$$
\Delta K=\Delta K_{C}=(1-R) \cdot K_{C}
$$

gdzie:

$\mathrm{K}_{\mathrm{C}}$ - wielkość krytyczna współczynnika intensywności naprężeń w przypadku, kiedy pęknięcie osiagnie długość krytyczną $l_{K R} \mathrm{i}$ wystapi naprężenie krytyczne $\sigma_{\mathrm{kr}}$; współczynnik ten nazywany jest odpornościq na pękanie.

Przebieg krzywej propagacji pęknięcia jest zależny od następujących czynników:

$$
\begin{aligned}
& \Rightarrow \text { współczynnika asymetrii cyklu } \mathrm{R} \\
& \Rightarrow \text { materiału osi } \\
& \Rightarrow \text { temperatury } \\
& \Rightarrow \text { mediów, znajdujących się w otoczeniu. }
\end{aligned}
$$

Wpływ tych czynników jest różny na zakresy oddziaływania tzn. na zakres $1 \mathrm{z}$ małą prędkością propagacji, na zakres 2 ze średnią prędkością propagacji oraz na zakres 3 z dużą prędkością propagacji pęknięcia. Ww. przedziały mają charakter umowny. Przykładowo wzrost współczynnika asymetrii cyklu $\mathrm{R}$ wywołuje większą prędkość propagacji pęknięcia da/dN w 1 i 3 zakresie aniżeli w zakresie 2 . Aby można było przeprowadzić prognozowanie żywotności konieczny jest opis krzywej prędkości propagacji wg następującej zależności:

$$
\frac{d a}{d N}=f(\Delta K, R)
$$

W tym przypadku występuje wiele koncepcji propagacji pęknięć. Tzw. prawo Parisa opisuje tylko i wyłącznie średni zakres (zakres 2), gdzie prędkość propagacji pęknięcia zmęczeniowego można ustalić tylko i wyłącznie w średnim zakresie krzywej prędkości propagacji pęknięcia zmęczeniowego. Ww. prędkość propagacji można wyznaczyć ze wzoru P.Parisa:

$$
\frac{d a}{d N}=C_{P} \cdot K^{m_{P}}
$$

Zarówno $\mathrm{C}_{\mathrm{P}}$ jak również $\mathrm{m}_{\mathrm{P}}$ są współczynnikami doświadczalnymi, zależnymi od rodzaju materiału, $\mathrm{z}$ którego zbudowany jest element konstrukcyjny. Ponieważ prawa tego nie można zastosować dla dolnego zakresu prędkości propagacji pęknięcia zmęczeniowego, nie można go również stosować do prognozowania żywotności, ponieważ ogólnie biorąc prowadzi to do bardzo zachowawczych obliczeń żywotności. Wzór Parisa uznaje się za pierwszą zależność, w której uwzględniono wielkości z mechaniki pękania. W przeciwieństwie do prawa Parisa wzór wg Formana-Mettu opisuje krzywą propagacji pęknięcia w zależności od współczynnika asymetrii cyklu zmęczeniowego R:

$$
\frac{d a}{d N}=C_{F M}\left[\frac{(1-\gamma)}{(1-R)} \cdot \Delta K\right]^{n_{F M}} \frac{\left(1-\frac{\Delta K_{t h}}{\Delta K}\right)^{p}}{\left(1-\frac{K_{M A X}}{K_{C}}\right)}
$$

Parametry $\Delta \mathrm{K}_{\mathrm{Th}}$ (zakres progowego współczynnika intensywności naprężeń), $\mathrm{K}_{\mathrm{C}}, \mathrm{C}_{\mathrm{FM}}, \mathrm{n}_{\mathrm{FM}}, \mathrm{p}$ oraz $\mathrm{q}$ są zależne od gatunku materiału i można je ustalić na drodze doświadczalnej krzywej da/dN. Za wielkość $\mathrm{K}_{\text {th }}$ należy uważać taką wielkość $\mathrm{K}_{\mathrm{MAX}}$, dla której pęknięcie nie rozwija się w okresie odpowiadającym $10^{6}$ cykli, a której zwiększenie o 3\% powoduje rozwój pęknięcia z prędkością nie większą od $3 \cdot 10^{-7} \mathrm{~mm} / \mathrm{cykl}$. Szczątkową (resztkową) wytrzymałość zmęczeniową elementu konstrukcyjnego aż do pęknięcia, można ustalić wychodząc z głębokości początkowej pęknięcia $a_{A}$ poprzez całkowanie równania propagacji prędkości tworzenia się rysy. Przekształcając równanie (5) otrzymuje się zależność:

$$
d N=\frac{d a}{f(\Delta K, R)}
$$

Stąd można wyliczyć resztkową (szczątkową) wytrzymałość zmęczeniową $\mathrm{N}_{\mathrm{B}}$ aż do wystapienia pęknięcia (krytyczna głębokość pęknięcia $\mathrm{a}_{\mathrm{C}}$ ):

$$
N_{B}=\int_{a_{A}}^{a_{C}} \frac{d a}{f(\Delta K, R)}
$$

\subsection{Analityczne i numeryczne badania propagacji pęknięć zmęczeniowych}

Do obliczeń wstępnych propagacji części i konstrukcji są do dyspozycji programy obliczeniowe, które zawierają rozwiązania analityczne dla określonych przypadków tworzenia się rys zmęczeniowych. $\mathrm{Z}$ drugiej strony występują programy za pomocą których można symulować metodą numeryczną propagację pęknięcia. 
Dla prac studialnych nad parametrami propagacji rysy $\mathrm{w}$ częściach konstrukcyjnych $\mathrm{z}$ relatywnie prostą geometrią szczególnie przydatne są programy Nasgro oraz Esacrack. Program Nasgro, który wcześniej był opracowany przez NASA (ang. ,National Aeronautics und Space Administration") posiada duże zastosowanie dla pojazdów lotniczych i kosmicznych. Nie mniej jednak można go stosować w wielu innych dziedzinach techniki. Główny moduł Nasfla umożliwia między innymi badania propagacji pęknięcia w elementach i konstrukcjach przy cyklicznym obciążeniu. Struktura tego programu jest przedstawiona w tabeli 1.

Istotne moduły programu Nasgro do badań propagacji pęknięcia w elementach konstrukcyjnych Tabela 1

\begin{tabular}{|c|c|c|}
\hline \multicolumn{3}{|c|}{ NASGRO } \\
\hline \multirow{4}{*}{ NASFLA } & $\begin{array}{c}\text { Badania propagacji } \\
\text { pęknięć zmęczeniowych }\end{array}$ & NASMAT \\
\cline { 2 - 2 } & $\begin{array}{c}\text { Obliczenie krytycznej } \\
\text { długości pęknięcia }\end{array}$ & $\begin{array}{c}\text { Bank danych } \\
\text { dotyczących } \\
\text { materiału }\end{array}$ \\
\cline { 2 - 2 } & $\begin{array}{c}\text { Obliczenie współczyn- } \\
\text { nika intensywności na- } \\
\text { prężeń }\end{array}$ & \\
\hline
\end{tabular}

Program składa się z biblioteki konfiguracji geometrycznych i pęknięć (rys) zmęczeniowych z odpowiednimi rozwiązaniami współczynników intensywności wzrostu naprężeń. Konstruując na tych konfiguracjach pęknięć (rys) można przeprowadzić symulację propagacji dla stałych i zmiennych amplitud obciążenia. Ponieważ program Nasgro sprawdził się w zastosowaniach praktycznych, można go zastosować w propagacji pęknięć zmęczeniowych zestawów kołowych.

\subsection{Czynniki wpływające na propagację uszkodzeń w osiach zestawów kołowych}

Aby przeprowadzić symulację propagacji pęknięć w osiach zestawów kołowych, stosuje się wyżej omówiony program Nasgro. Za pomocą obliczeń wariacyjnych powinno się pokazać jakie poszczególne czynniki działają na propagację pęknięcia zmęczeniowego:

- wielkość zespołu (kombinacji) obciążeń

- naprężenia montażowe (naprężenia średnie)

- dane materiałowe $\mathrm{z}$ uwagi na mechanikę pękania

- głębokość / długość wykrytego pęknięcia zmęczeniowego

- efekty sekwencyjne.

Symulacje propagacji pęknięcia dla osi zestawów kołowych dostarczają wytycznych dla ustalenia okresów kontrolnych za pomocą badań nieniszczących. Do symulacji dla osi zespołów trakcyjnych ICE przystosowanych do wysokich prędkości stosuje się model SC05 wg programu SC05. Model składa się z osi drążonej z półeliptycznym pęknięciem, znajdującym się na powierzchni o głębokości ,a” oraz długości „2c” (rys.3).
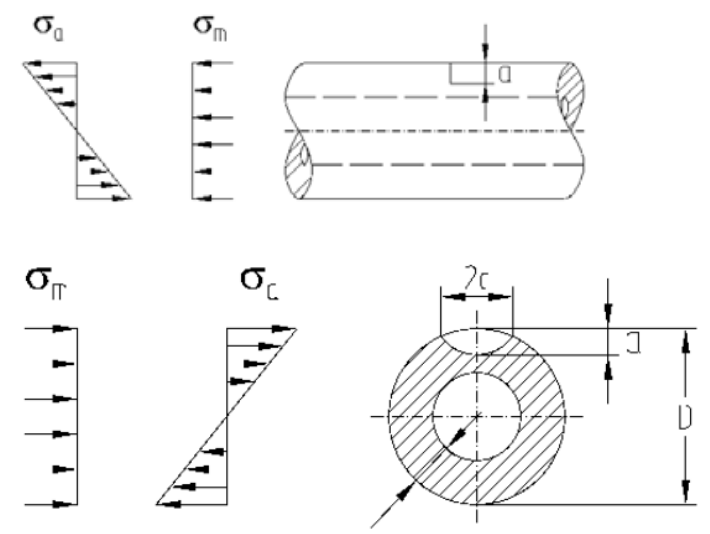

\section{Legenda:}

a) naprężenie maksymalne: $\sigma_{0}=\sigma_{m}+\sigma_{a}$

b) naprężenie średnie: $\sigma_{m}$

Rys.3. Model pęknięcia SC05 wg programu Nasgro

Niniejszy model przedstawia rzeczywiste pęknięcie, który występuje $\mathrm{w}$ osi zestawu kołowego $\mathrm{w}$ pobliżu miejsca na osadzenie. W tym modelu pęknięcia jest możliwe, aby dokonać superpozycji stałego naprężenia i naprężenia zginającego. W obliczeniach osi zestawów kołowych naprężenie zginające odpowiada kombinacji amplitud w płaszczyźnie pęknięcia. Naprężnie o wartości stałej przedstawia naprężenie normalne, które występuje w pobliżu osadzania koła (podpiaścia) i jest ono wywołane przez siły montażu koła na osi zestawu kołowego. Dla obliczeń propagacji pęknięcia wielkościami zmiennymi są amplituda naprężenia, naprężnie średnie i geometria początkowego pęknięcia. Górną wartość naprężenia $\sigma_{0}$ można wyznaczyć z zależności:

$$
\sigma_{0}=\sigma_{m}+\sigma_{a}
$$

gdzie:

$\sigma_{\mathrm{m}}$ - naprężenie średnie

$\sigma_{\mathrm{a}}$ - amplituda naprężenia.

Kumulacja naprężeń dla badanych osi zestawów kołowych jest przedstawiona na rys. 4 .

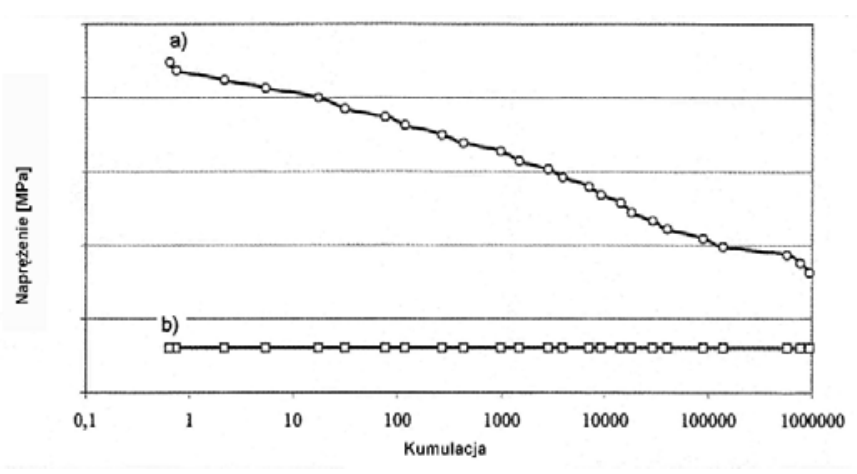

Rys.4. Kumulacja obciążeń dla badanych osi zestawów kołowych 
Za pomoca programu Nasgro można obliczyć kształt pęknięcia dla każdego cyklu. Kształt pęknięcia półeliptycznego o głębokości „a” oraz długości pęknięcia „2c” jest punktem wyjścia dla propagacji pęknięcia. Symulację przeprowadza się tak długo, aż współczynnik intensywności naprężeń $\mathrm{K}_{\mathrm{MAX}}$ osiagnie wartość $\mathrm{K}_{\mathrm{C}}$. Z otrzymanych wartości można wyznaczyć głębokość pęknięcia w zależności od przebiegu kilometrowego, co jest pokazane na rys. 5, 6 i 7 .

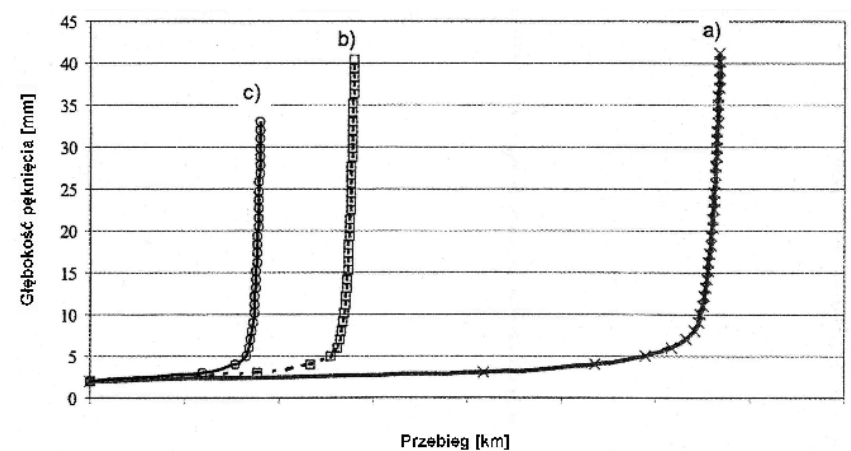

Rys.5. Zależność głębokości pęknięcia od przebiegu pojazdu w kilometrach; wpływ wielkości wytężenia materiału na propagację pęknięć w osiach zespołów trakcyjnych ICE a) zespół amplitud wyprowadzony z jazd próbnych b) zespół amplitud zwiększony o $10 \%$ c) zespół amplitud zmniejszony o 10

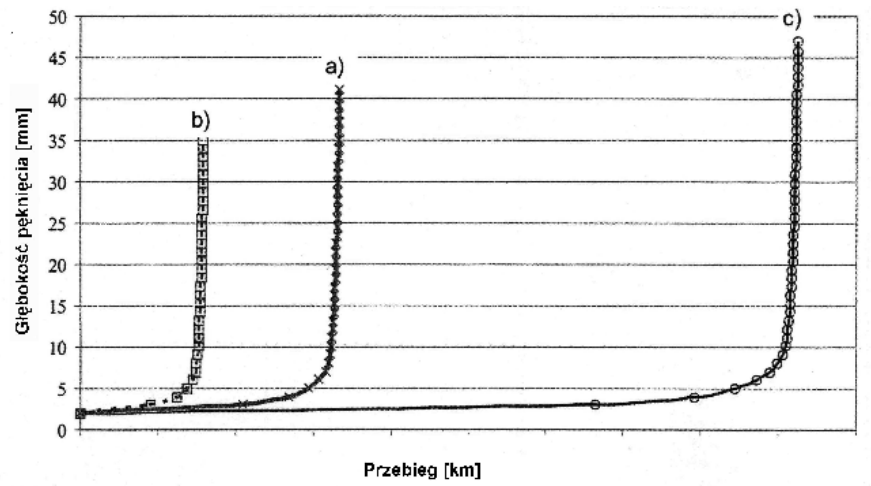

Rys.6. Zależność głębokości pękania od przebiegu pojazdu w kilometrach; wpływ średniego naprężenia na przebieg osi zestawu kołowego z pęknięciem a) zespół amplitud wyznaczony $\mathrm{z}$ jazd próbnych b) zespół $\mathrm{z}$ naprężeniem średnim 20,5 MPa c) zespół z naprężeniem średnim $30,5 \mathrm{MPa}$

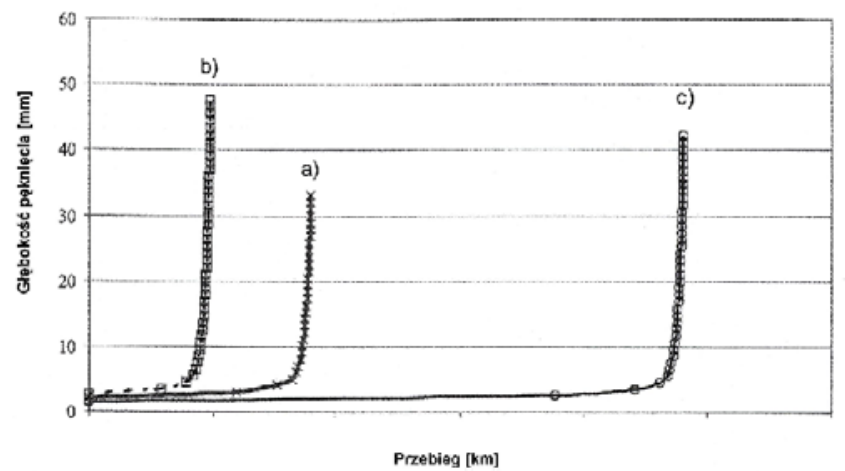

Rys.7. Wpływ głębokości początkowej pęknięcia na przebieg osi zestawu kołowego; a) głębokość pęknięcia początkowego $\mathrm{a}_{\mathrm{A}}=2,0$ $\mathrm{mm}$ b) głębokość pęknięcia początkowego $\mathrm{a}_{\mathrm{A}}=2,5 \mathrm{~mm}$ c) głębokość pęknięcia początkowego $\mathrm{a}_{\mathrm{A}}=1,5 \mathrm{~mm}$
Badania symulacyjne dostarczają wytycznych do ustalenia okresów kontrolnych dla badań nieniszczących osi zestawów kołowych. Należy zwrócić przy tym uwagę, że symulacje komputerowe można przeprowadzać dla osi zestawów kołowych przy uwzględnieniu wszystkich czynników. Jak wykazały przeprowadzone prace studialne znaczący wpływ na przebieg osi maja już małe zmiany tych czynników.

\section{Ustalenie okresów kontrolnych osi zestawów kołowych na przykładzie zespołów trakcyjnych metra}

\subsection{Uwagi ogólne}

Zagadnienie wytrzymałości zestawów kołowych uznano jako bardzo ważne $\mathrm{z}$ punktu widzenia dyspozycyjności i bezpieczeństwa eksploatacyjnego pojazdów trakcyjnych metra firmy Hamburger Hochbahn AG. Częstotliwość kontroli stanu osi zestawów kołowych podczas eksploatacji jest wprawdzie zdefiniowana przez producenta $\mathrm{w}$ instrukcji obsługi i konserwacji, ale ostatecznie przyjęto założenie że to użytkownik musi opracować program kontroli stanu osi zestawów kołowych, gdyż zna rzeczywiste warunki eksploatacji i dysponuje odpowiednim doświadczeniem. Jako bazę do późniejszych rozważań na ww. temat przyjęto badania ultradźwiękowe. Czynniki wpływające na ograniczenie wytrzymałości zmęczeniowej można podzielić na trzy grupy:

- błędy powstające na etapie produkcji (konstrukcja, produkcja i obróbka wykańczająca)

- błędy eksploatacyjne (nieodpowiednia eksploatacja, błędy popełnione podczas procesów kontrolno-naprawczych)

- nadzwyczajne wydarzenia podczas eksploatacji (obciążenia nadzwyczajne, działanie czynników obcych, wypadki kolejowe).

Opracowując nowe instrukcje kontroli należy wziąć pod uwagę, aby wykryć lub uniknąć występowania ww. błędów, które w istotny sposób zmniejszają wytrzymałość zmęczeniową osi. Jako granicę żywotności osi zestawu kołowego uznaje się wystapienie przeło$\mathrm{mu}$ zmęczeniowego lub wystapienie pęknięcia. Aby uniknać pęknięć osi zestawu kołowego bierze się z podstawę koncepcję „safe-life", natomiast w celu uniknięcia przełomów zmęczeniowych bierze się za podstawę koncepcję „fail-safe”. Dotychczasowa eksploatacja zestawów kołowych bazowała na koncepcji „safe-life" i wychodziła z metody projektowania polegającej na przyjęciu kryterium bezpieczeństwa jakim jest granica wytrzymałości zmęczeniowej. Wadą takiego projektowania osi zestawów kołowych jest to, ze nie jest określona żadna wartość graniczna, przy której oś może być jeszcze eksploatowana. Osie zestawów kołowych pojazdów kolejowych, które są eksploatowane w warunkach ruchu miejskiego osiagają $2 \times 10^{9}$ cykli i znajdują się w warunkach wysokocyklicznej wytrzymałości zmęczeniowej (ang. 
„high-cycle-fatique”), która nie została jeszcze dokładnie zbadana. Jak wynika $\mathrm{z}$ praktyki eksploatacyjnej osie zestawów kołowych mogą być eksploatowane przez bardzo długi czas, wynikający z przebiegu pojazdu szynowego. Jeśli określi się graniczny przebieg $\mathrm{W}$ kilometrach, to ryzyko eksploatacyjne jest bardzo małe, ponieważ okresy kontrolne stanu osi zestawów kołowych ograniczaja się do potwierdzenia prawidłowości przyjętych obciążeń podczas projektowania. Największe ryzyko eksploatacyjne występuje wtedy, gdy zostanie osiagnięta faza eksploatacji, kiedy należy się liczyć z wystąpieniem pęknięć zmęczeniowych. W tym przypadku należy skorzystać z koncepcji „fail-safe”, która uwzględnia nałożenie się wielu niekorzystnych zdarzeń. W takiej fazie eksploatacji należałoby zabezpieczyć przebieg eksploatacyjny po wystapieniu pęknięcia. Kontrole, które obecnie muszą wynikać z propagacji pęknięcia, służą wykryciu rysy. Pomiędzy dwoma ekstremami występuje faza przejściowa, w której nie można $\mathrm{z}$ całkowitą pewnością wykluczyć powstania pojedynczych pęknięć, ale zasadniczo nie są one oczekiwane. Prawdopodobieństwo wystapienia pojedynczych pęknięć zmęczeniowych jest wyraźnie małe. W takiej fazie eksploatacyjnej okresy kontrolne wynikają z propagacji pęknięć. Biorąc pod uwagę koncepcję bezpieczeństwa, należy wyjść z nałożenia się wielu niekorzystnych zdarzeń. Tak więc należy wyjść z założenia, że występują trzy zadania przy określaniu koncepcji okresów kontrolnych stanów osi zestawów kołowych:

- określenie granicznych przebiegów na bazie doświadczeń eksploatacyjnych przy uwzględnieniu koncepcji bezpieczeństwa wynikającej $\mathrm{z}$ granicy zmęczenia i niezawodności eksploatacji

- określenie szczątkowego (resztkowego) przebiegu po przyjęciu pęknięcia, biorąc pod uwagę aspekt mechaniki pękania $\mathrm{w}$ zakresie liniowym, jeśli chodzi o mechanikę pękania

- opracowanie zabiegów technicznych dla przejściowej fazy eksploatacyjnej.

\subsection{Obciążenia osi zestawów kołowych pojazdów trakcyjnych metra}

W celu zagwarantowania większej wiarygodności jeśli chodzi o wytrzymałość zmęczeniową jest konieczne, aby ustalić rzeczywiste obciążenia działające na oś zestawu kołowego. Obciążenia te wyznaczono dla starych osi zestawów kołowych pojazdów trakcyjnych typu DT3 metra (rys.8) oraz nowych osi zestawów kołowych dla pojazdów trakcyjnych typu DT4 (rys.9).

Odpowiednie dane dotyczące zestawów kołowych są przedstawione w tabeli 2

Na całej sieci Hamburger Hochbahn zostały pomierzone obciążenia eksploatacyjne dla osi tocznych oraz napędnych dla trzech pojazdów trakcyjnych. Jak wykazały przeprowadzone pomiary wysokość obciążenia zależy znacząco od następujących warunków eksploatacyjnych:

- stopnia obsadzenia przez podróżnych, przy czym główne oddziaływanie skierowane jest na obciążenie statyczne koła

- usytuowania osi zestawu kołowego w wózku (zestaw kołowy nabiegający lub swobodny)

- przejazd przez luk toru (ekstremalny przypadek eksploatacyjny $\mathrm{z}$ uwagi na obciążenia)

- zastosowanie rozruchu i hamowania jako dodatkowej superpozycji obciążeń.

Wartości pomiarowe, wynikające $\mathrm{z}$ jazdy w łuku zostały przeanalizowane bardzo dokładnie. Przeanalizowano łącznie 2000 jazd przez łuk, które wywołuja wysokie obciążenia podczas przejazdu dla osi tocznych i napędnych w przypadku zestawu kołowego nabiegającego. Poza tym stwierdzono:

- bardzo wyraźną zależność obciążenia osi od promienia łuku toru

- bardzo mały wpływ zarówno niezrównoważonego przyspieszenia poprzecznego jak również błędów ułożenia toru $\mathrm{w}$ ramach tolerancji eksploatacyjnych

- bardzo mały poziom obciążenia spowodowany momentem skręcającym.

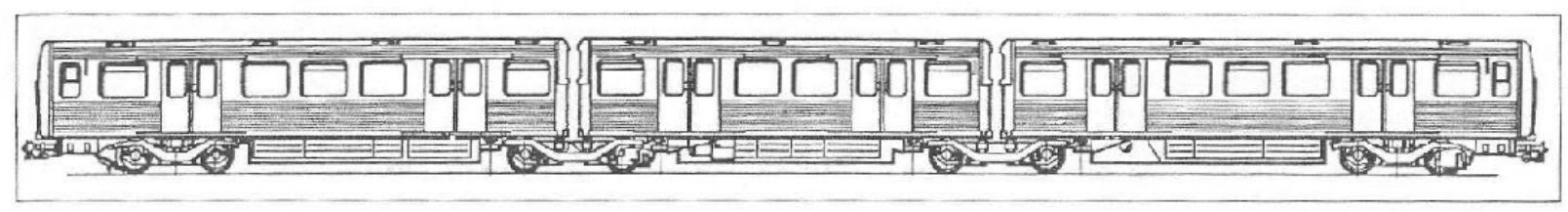

Rys.8. Zespół trakcyjny typu DT3 metra Hamburger Hochbahn AG [2]

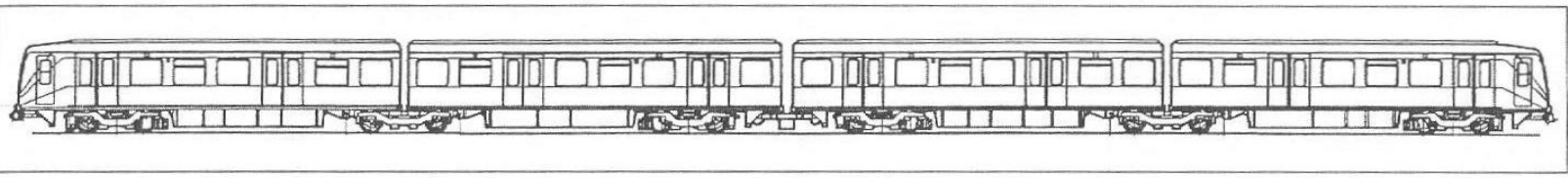

Rys.9. Zespół trakcyjny typu DT4 metra Hamburger Hochbahn AG [2] 
Tabela 2

\begin{tabular}{|c|c|c|c|}
\hline Rok budowy & $\begin{array}{c}\text { Zespół trakcyjny typu } \\
\text { DT3 }\end{array}$ & $\begin{array}{c}\text { Zespół trakcyjny typu } \\
\text { DT4 }\end{array}$ & DT4, seria 5-6 \\
\hline Rok budowy & $1969 \div 1971$ & $1989 \div 2000$ & $2002 \div 2005$ \\
\hline Ilość zestawów kołowych & 544 & 1032 & 480 \\
\hline Konstrukcja & wg DB Blatt Fw28.02.8 & $\begin{array}{c}\text { ORE-Bericht B136/Rp11 } \\
{[12]}\end{array}$ & PN-EN 13104 [10] \\
\hline Przebieg & 3,4 miliona kilometrów & 2,0 miliona kilometrów & 0,7 miliona kilometrów \\
\hline Wyniki po kontroli UT & $\begin{array}{c}\text { Po wystąpieniu pęknięcia } \\
\text { zmęczeniowego po } 2,5 \\
\text { milionie cykli }\end{array}$ & Brak pęknięcia & Brak pęknięcia \\
\hline Średnica podpiaścia & $140 \mathrm{~mm}$ & $142 \mathrm{~mm}$ & $142 \mathrm{~mm}$ \\
\hline Materiał & 34CrMo4 & $25 \mathrm{CrMo} 4$ & $25 \mathrm{CrMo} 4$ \\
\hline
\end{tabular}

Ponieważ wyników pomiarów nie można było odnieść do normy PN-EN 13104:2009 [10] zbudowano dla tych pojazdów model obliczeniowy wg metody Heumanna, który uwzględnia opory tarcia przy obrocie kompletnego wózka na odcinkach prostych toru (rys.10).

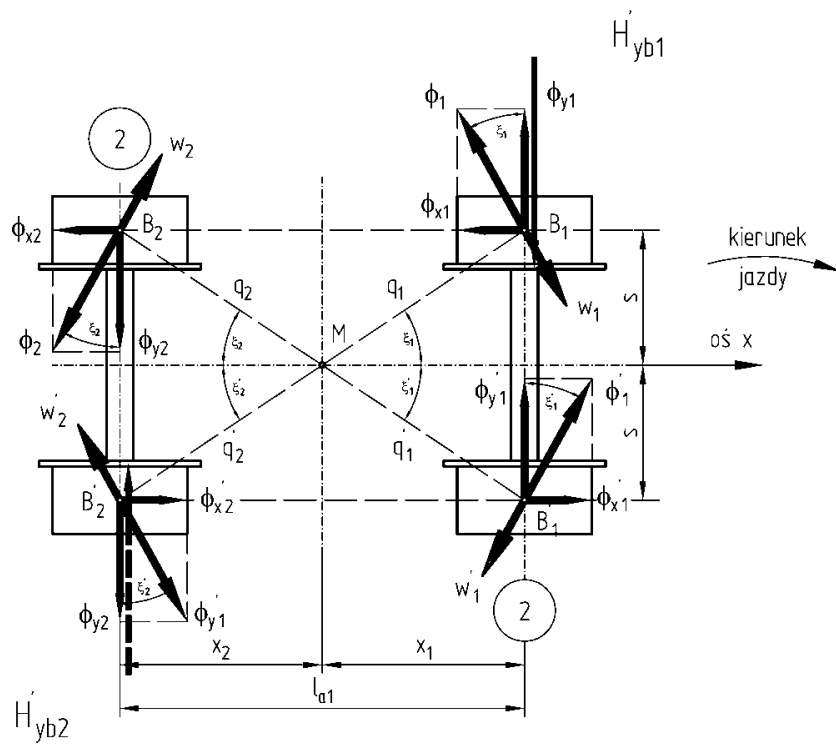

Rys.10. Siły działające na wózek podczas przejazdu przez łuk toru wg metody Heumanna

Uwzględniono, że przy wysokich obciążeniach podczas przejazdu przez małe promienie łuku toru $(\mathrm{R}<80$ $\mathrm{m})$, należy wziąć pod uwagę bardzo wysokie współczynniki przyczepności wynoszące $\mu=0,6$. Ponieważ warunki eksploatacyjne wpływają na rzeczywiste obciążenia osi zestawów kołowych, konieczne jest odtworzenie rzeczywistego „tła eksploatacyjnego”. Rzeczywiste warunki eksploatacyjne wynikają z tabeli 3 .

Stopień obsadzenia podróżnymi zespolów trakcyjnych metra Hamburger Hochbahn AG [2]

\begin{tabular}{|c|c|c|c|c|}
\hline $\begin{array}{c}\text { Stopień ob- } \\
\text { sadzenia } \\
\text { pojazdu }\end{array}$ & $\mathbf{0} \div \mathbf{2 5 \%}$ & $\mathbf{2 5 \div 5 0 \%}$ & $\mathbf{5 0 \div \mathbf { 7 5 } \%}$ & $\mathbf{7 5 \div 1 0 0 \%}$ \\
\hline $\begin{array}{c}\text { Ilość } \\
\text { pasażerów }\end{array}$ & $0 \div 138$ & $139 \div 277$ & $278 \div 415$ & $416 \div 554$ \\
\hline $\begin{array}{c}\text { Nacisk } \\
\text { zestawu } \\
\text { kołowego na } \\
\text { tor }\end{array}$ & $63 \div 72$ & $72 \div 81$ & $81 \div 90$ & $90 \div 100$ \\
\hline $\begin{array}{c}\text { Udział na } \\
\text { trasie }\end{array}$ & $77,5 \%$ & $21,2 \%$ & $1,28 \%$ & $0,02 \%$ \\
\hline \multicolumn{1}{|c|}{} & $\mathrm{kN}$ & $\mathrm{kN}$ \\
\hline
\end{tabular}

\subsection{Określenie przebiegu eksploatacyjnego bez wystąpienia pęknięć}

Określenie przebiegu bez występowania pęknięć można było przeprowadzić tylko dla osi zespołów trakcyjnych DT4 na bazie doświadczeń eksploatacyjnych zebranych z osi zestawów kołowych zespołów trakcyjnych typu DT3, które posiadały większy przebieg kilometrowy. Przyjęto założenie, że można uwzględniać tylko pozytywne doświadczenia eksploatacyjne, ale zdobyte tylko $\mathrm{z}$ rzeczywistymi obciążeniami eksploatacyjnymi, a nie $z$ obciążeniami przyjętymi na etapie projektowania i zaczerpniętymi $\mathrm{z}$ odpowiednich przepisów. W przypadku osi zestawu kołowego zespołu trakcyjnego typu DT3 wykryto pęknięcie po przebiegu wynoszącym 2,5 miliona kilometrów. Pęknięcie to znajdowało się na podpiaściu pod piasta koła. Nie wykryto dalszych pęknięć podczas regularnych badań ultradźwiękowych, pomimo że zespoły trakcyjne przejechały dalsze $900000 \mathrm{~km}$. Doświadczenia eksploatacyjne zostały odpowiednio udokumentowane i przestudiowane. Porównanie cyklicznego obciążenia trzech konstrukcji zestawów kołowych zespołów trakcyjnych DT3 i DT4 w poszczególnych przekrojach osi przedstawiono na rys.11. 


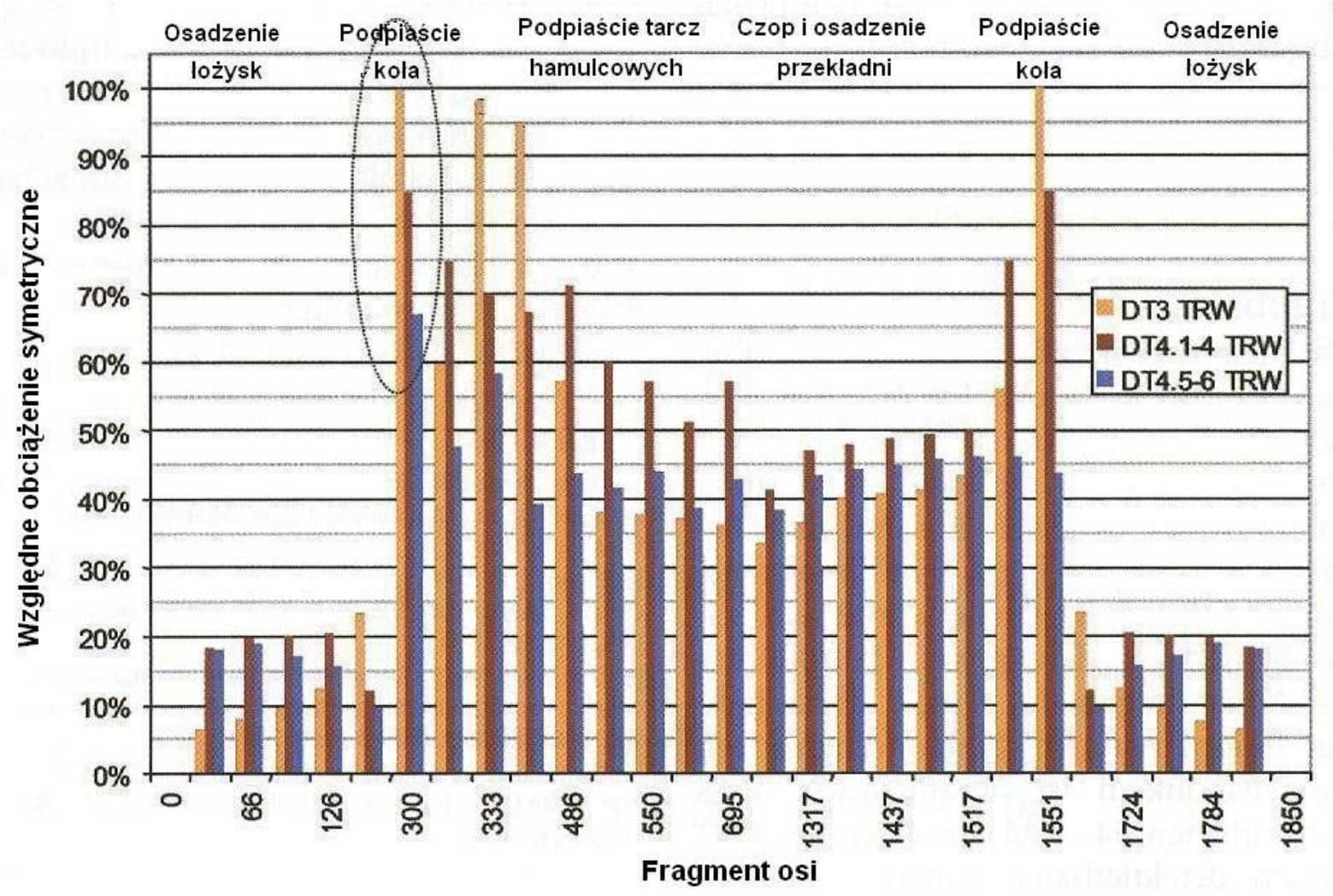

Rys.11. Porównanie względnych obciążeń osi zestawów kołowych w poszczególnych prze krojach dla zespołów trakcyjnych typu DT3, DT4.1-4 oraz DT4.5-6 [2]

Jak wynika z porównania graficznego najbardziej wytężonym fragmentem osi zestawu kołowego jest wewnętrzna krawędź osadzenia (podpiaścia) koła i można go uznać jako „miejsce krytyczne”. Przyjmując wytężenie materiału $\mathrm{w}$ tym miejscu dla osi zestawu kołowego $100 \%$, okazuje się, że miejsce to jest obciążone $85 \%$ dla osi zestawu kołowego zespołu trakcyjnego typu DT4.1-4 oraz 67\% dla osi zestawu kołowego zespołu trakcyjnego typu DT4.5-6. Koncepcja zapewnienia bezpieczeństwa eksploatacyjnego polega na określeniu sumy uszkodzeń D, którą można ustalić z hipotezy kumulacji uszkodzeń na podstawie krzywej Wöhlera. Korzystne jest to, że można włączyć wszystkie działające obciążenia zewnętrzne do „działania powodującego uszkodzenia”. Wadą jest duży wpływ przebiegu krzywej Wöhlera danego elementu konstrukcyjnego na wybór hipotezy kumulacji uszkodzeń, co powoduje że obliczenie wytrzymałości eksploatacyjnej bez przeprowadzenia równoległych badań nie może dostarczyć absolutnie pewnych wyników. Bardzo przydatne są obliczenia wytrzymałości eksploatacyjnej za pomocą fikcyjnych krzywych Wöhlera do oceny rzeczywistych warunków eksploatacyjnych. $\mathrm{Na}$ bazie zaproponowanej metody do ustalenia ekwiwalentnej amplitudy wywołującej uszkodzenia należy określić sumę uszkodzeń dla poszczególnych osi zestawów kołowych, wskutek czego można porównać wzajemnie przebiegi eksploatacyjne bez pęknięcia. Obliczenia cyklicznych naprężeń wykazały, że wewnętrzna krawędź podpiaścia (osadzenia) koła jest najbardziej wytężonym przekrojem osi. Określenie sumy uszkodzeń odbyło się na bazie mieszanego zespołu obciążeń, stosownie do różnych przebiegów eksploatacyjnych pojazdów. Aby określić sumę uszkodzeń wyznacza się fikcyjną krzywą Wöhlera za pomocą dwóch różnych metod. Obydwie metody odpowiadają modyfikacji hipotezy uszkodzeń wg Minera zgodnie ze wzorem:

$$
n_{i}=n_{D}\left(\frac{\sigma_{D}}{\sigma_{i}}\right)^{k}
$$

Obydwie metody 1 i 2 różnią się wzajemnie parametrami, co jest przedstawione w tabeli 4.

Parametry fikcyjnych krzywych Wöhlera wg metody 1 i 2

Tabela 4

\begin{tabular}{|c|c|c|}
\hline Określenie & Metoda 1 & Metoda 2 \\
\hline $\begin{array}{c}\text { Punkt załamania krzywej } \\
\text { Wöhlera }\end{array}$ & $10^{6}$ & $10^{7}$ \\
\hline $\begin{array}{c}\text { Współczynnik pochylenia } \\
\text { krzywej Wöhlera przed } \\
\text { punktem załamania k= } \mathrm{k}_{1}\end{array}$ & 7 & 5 \\
\hline $\begin{array}{c}\text { Współczynnik pochylenia } \\
\text { krzywej Wöhlera przed } \\
\text { punktem załamania k=k }\end{array}$ & $\mathrm{k}_{2}=2 \mathrm{k}_{1}-1$ & $\mathrm{k}_{2}=2 \mathrm{k}_{1}-2$ \\
\hline $\begin{array}{c}\text { Suma uszkodzeń do } \\
\text { określenia naprężenia na } \\
\text { punkcie załamania D krzywej } \\
\text { Wöhlera }\end{array}$ & 0,3 & 0,5 \\
\hline \multicolumn{2}{|c|}{}
\end{tabular}


Sumę uszkodzeń tworzy się z udziałów uszkodzeń „n” klas naprężeń wg następującej zależności:

$$
D=\sum_{i=1}^{n} D_{i}
$$

Doświadczenia eksploatacyjne wykazały, że nie powstało żadne pęknięcie osi zestawu kołowego napędnego zespołu trakcyjnego typu DT3 po osiagnięciu przebiegu wynoszącego 2,5 miliona kilometrów. W wyniku obliczeń granicy zmęczenia dla osadzenia koła dla zespołów trakcyjnych typu DT4.1-4 oraz DT4.5-6 okazało się, że jest ona odpowiednio o $26 \%$ oraz $18 \%$ większa niż dla zespołu trakcyjnego DT3, co wykazują następujące zależności:

$$
\begin{array}{r}
\sigma_{\mathrm{D}} \cdot(\mathrm{DT} 4.1-4)=1,26 \cdot \sigma_{\mathrm{D}}(\mathrm{DT} 3) \\
\left.\sigma_{\mathrm{D}} \cdot(\mathrm{DT} 4.5-6)=1,18 \cdot \sigma_{\mathrm{D}} \text { DT3 }\right)
\end{array}
$$

Sumę uszkodzeń D dla poszczególnych osi zestawów kołowych przedstawiono w tabeli 5.

Suma uszkodzeń D dla poszczególnych osi zestawów kołowych zespołów trakcyjnych DT3 i DT4 Hamburger Hochbahn AG wg [2] Tabela 5

\begin{tabular}{|c|c|c|}
\hline Suma uszkodzeń & Metoda 1 & Metoda 2 \\
\hline Zespół trakcyjny typu DT3 & 0,03 & 0,5 \\
\hline Zespół trakcyjny typu DT4.1-4 & 0,05 & 0,18 \\
\hline Zespół trakcyjny typu DT4.5-6 & 0,002 & 0,027 \\
\hline
\end{tabular}

\subsection{Podsumowanie wyników przeprowadzonych badań oraz analiz}

Tak więc przedsiębiorstwo Hamburger Hochbahn AG dysponuje 35-cio letnimi doświadczeniami w zakresie eksploatacji osi zestawów kołowych zespołu trakcyjnego typu DT3. Doświadczenia te odnoszą się do przebiegu wynoszącego maksymalnie 3400000 km. Po przebiegu 2500000 kilometrów wykryto pęknięcie $\mathrm{w}$ jednej osi zestawu kołowego. W wyniku przeprowadzonej kontroli za pomocą badań ultradźwiękowych okazało się, że pozostałe 543 zespołów trakcyjnych typu DT3 osie nie wykazały żadnych pęknięć. Biorąc pod uwagę, że sieć kolejowa metra jest zamknięta, sposób eksploatacji w przedsiębiorstwie przewozowym, jak również baza danych jest określona przez pomiary, obciążenia są wyznaczane wystarczająco dokładnie. Dane te mogę służyć jako baza referencyjna. Poprzez obliczenia $\mathrm{z}$ uwzględnieniem obciążeń, przyjętych z rzeczywistej eksploatacji można udowodnić na podstawie koncepcji bezpieczeństwa opartej o kryteria wytrzymałości zmęczeniowej oraz eksploatacyjnej można udowodnić, że zarówno względne cykliczne obciążenia jak również względne kumulacje uszkodzeń dla osi zestawów kołowych zespołu trakcyjnego typu DT4 wypadają korzystniej aniżeli dla zespołu trakcyjnego typu DT3. Można stwierdzić, że dla osi zestawów kołowych zespołów trakcyjnych typu DT4 występuje duży zapas bezpieczeństwa, który gwarantuje przebieg wynoszący 2500000 kilometrów bez wystąpienia pęknięcia, pod warunkiem że nie ma oddziaływań żadnych nadzwyczajnych obciążeń.

\section{Znaczenie badań nieniszczących}

\subsection{Uwagi ogólne}

Aby zapewnić prawidłowy przebieg procesu prognozowania stanu osi zestawów kołowych pojazdów trakcyjnych konieczne jest prawidłowe przeprowadzenie badań nieniszczących. One umożliwiają rozstrzygnięcie, czy badana część konstrukcyjna lub badany podzespół w zależności od ustalonych przepisów naprawczych może być dalej eksploatowana lub wymontowana względnie naprawiana. $Z$ przeprowadzonej analizy wynika, że badania nieniszczące muszą być wykonane w sposób niezawodny, gwarantujący odpowiedni poziom jakości.

Badania nieniszczące można zaliczyć do procesów specjalnych tj. procesów, które $\mathrm{z}$ uwagi na ich dużą subiektywność ocen, powodują że ich wiarygodność zależy od wielu różnorodnych czynników i działań, wymagających odpowiednich kwalifikacji oraz przeprowadzenia walidacji/kwalifikacji ich zdolności do określonego celu oraz potwierdzenia określonych kompetencji. Do takich czynników i działań można zaliczyć te przedstawione poniżej i które można połączyć w tzw. łańcuch zapewnienia jakości jaki powinien być zastosowany celem spełnienia i akceptacji określonych wymagań oraz potwierdzenia określonych kompetencji:

1. Badania naukowe i rozwój badań nieniszczących

2. Normalizacja w dziedzinie badań nieniszczących

- normy wyboru i badań

- specyfikacje techniczne

- przepisy techniczne

3. Procedury/instrukcje badawcze badań nieniszczących

- walidacja i kwalifikacja procedur/ instrukcji badawczych

- niepewność pomiaru /badania

4. Wyposażenie pomiarowe i badawcze ( WP i B)

- wzorcowania/kontrola/ charakterystyka/nadzór nad WP i B

- walidacja i kwalifikacja WP i B

- szkolenia w zakresie wykorzystania WP i B

5. Personel przeprowadzający badania nieniszczące

- szkolenie i certyfikacja personelu badań nieniszczących

- certyfikacja personelu badań nieniszczących

- upoważnienie i nadzór nad personelem

- czynnik ludzki- cechy i czynniki psychofizyczne

6. Środowisko przeprowadzenia badań

7. Audity 
Spełnianie przedstawionych zależności może być uzyskane w przypadku, jeżeli:

- każdy z wymienionych elementów będzie oddziaływał w sposób skuteczny na inne

- pod warunkiem spełnienia odpowiednich wymagań i kryteriów akceptacji lub kwalifikacji (np. spełnienia odpowiednich wymagań, kryteriów akceptacji lub kwalifikacji metody)

- sam element będzie „mocny” np. stanem dotyczących swego udokumentowania (normami, specyfikacjami lub wytycznymi) lub zapewnieniem odpowiednich instrukcji stosowania lub określonych uznanych zasad kwalifikacji personelu przeprowadzającego odpowiednie badania.

Zasadniczym warunkiem zapewnienia jakości badań nieniszczących jest ustanowienie odpowiedniego systemu zarządzania jakością w celu sterowania wszystkimi działaniami, które dotyczą jakości świadczonych usług badawczych. System jakości producenta, jednostki badawczej lub laboratorium badawczego prowadzącego badania nieniszczące powinien uwzględniać w ,jednolity i uporządkowany sposób”, a przede wszystkim w skuteczny sposób przedstawione wyżej elementy łańcucha zapewnienia jakości w celu wykazania, że wszystkie zostały przewidziane $\mathrm{i}$ istnieją między nimi zależności i relacje.

\subsection{Status badań nieniszczących zgodnie $\mathrm{z}$ kartą UIC 960 [8]}

Zgodnie z kartą UIC 960 [8] przez badania nieniszczące definiuje się jako metody, które przeprowadza się bez uszkodzenia części pojazdu lub podzespołów i które służą wykryciu możliwych pęknięć (rys) lub innych uszkodzeń spowodowanych w eksploatacji podczas napraw.

W zapewnieniu prawidłowej jakości badań nieniszczących istotnym czynnikiem jest kwalifikacja i certyfikacja personelu do badań, co jest szczegółowo przedstawione w karcie UIC 960 [8]. Zgodnie z niniejszą kartą:

- kwalifikacja pracownika polega na uznaniu jego zawodowej wiedzy, jego zdolności, doświadczenia i przydatności fizycznej, wskutek czego jest w stanie, aby wykonać powierzone mu zadania $\mathrm{W}$ zakresie badań nieniszczących. W przypadku certyfikacji chodzi o metodę, w wyniku której niezależna instytucja udziela pisemnego zapewnienia co do tego, że sprawdzający metodami nieniszczącymi posiada niezbędne kompe-tencje W zgodności z ustalonymi warunkami ramowymi w normie europejskiej EN 473 [5]. Powyższa norma zawiera przepisy na temat udzielania certyfikatu dla kwalifikowanych pracowników.
- autoryzacja badawcza polega na uznaniu kompetencji i wystawieniu wykwalifikowanemu pracownikowi zgodnie z EN 473 [5] pisemnej autoryzacji badawczej przez przełożonych przy uwzględnieniu szczególnych wiadomości i przydatności do pracy jak również znajomości przepisów bezpieczeństwa i higieny pracy, które należy przestrzegać.

- niezależna instytucja certyfikująca administruje metodami certyfikacji personelu do badań nieniszczących $\mathrm{w}$ zgodności $\mathrm{z}$ normą europejską EN 473 [5] i wymaganiami normy europejskiej EN 45013 [6]. W większości krajów Unii Europejskiej działają niezależne instytucje, które są akredytowane przez instancje krajowe.

- autoryzowana instytucja certyfikująca jest całkowicie niezależna $\mathrm{i}$ jest autoryzowana przez niezależną instytucję, aby przygotować i przeprowadzać badania kwalifikacyjne personelu do badań nieniszczących. W przypadku kwalifikacji i certyfikacji przedstawionej w niniejszej karcie chodzi o Komitet Certyfikacyjny Kolejnictwa do Napraw, który był autoryzowany przez niezależna, krajową instytucję do przeprowadzenia certyfikacji w zakresie napraw krajowych.

- centrum badawcze jest dopuszczone bezpośrednio przez niezależną instytucję lub przez autoryzowaną instytucję, w której odbywają się badania kwalifikacyjne. W tym przypadku chodzi o centrum, które dysponuje odpowiednimi kompetencjami, urządzeniami i pomieszczeniami do badań $\mathrm{w}$ jednym $\mathrm{z}$ obszarów zastosowań napraw kolejowych:

1. zestawy kołowe (koła, pełne osie i osie drążone, układy biegowe)

2. wózki i połączenia (ramy wózków, wahacze, prowadniki, pojedyncze części jak również części usprężynowania urządzenia cięgłowozderznego).

Wykaz instytucji certyfikujących oraz instytucji akredytujących jest przedstawiony w tabeli 6 .

a. ZFP: badania nieniszczące

Instytucje certyfikujące

DGZfP-DPZ- Niemieckie Towarzystwo dla Badań Nieniszczących-Ośrodek Certyfikujący Personel

BANT- Belgijskie Stowarzyszenie Badań Nieniszczących

COFREND- Francuskie Stowarzyszenie Badań Nieniszczących

PCN- Ośrodek Certyfikacji Personelu dla Badań Nieniszczących

CIC-PND- Włoski Ośrodek Badań Nieniszczących 
Wykaz instytucji certyfikujących oraz akredytujących zgodnie z zalącznikiem A karty UIC 960 [8]

Tabela 6

\begin{tabular}{|c|c|c|c|c|}
\hline \multirow{2}{*}{$\begin{array}{c}\text { Kraj Unii } \\
\text { Europejskiej }\end{array}$} & \multirow{2}{*}{$\begin{array}{c}\text { Instytucja } \\
\text { certyfikująca } \\
\text { personel dla } \mathrm{ZFP}^{\mathrm{a}}\end{array}$} & \multicolumn{2}{|c|}{ Akredytacja } & \multirow{2}{*}{$\begin{array}{c}\text { Autoryzowana } \\
\text { instytucja kolejowa } \\
\text { lub równorzędna }\end{array}$} \\
\hline & & Data & Krajowa instytucja & \\
\hline Niemcy & $\overline{\text { DGZfP }}$ & 1.3 .1994 & TGA & $\overline{\text { DGZfP(DGZ) }}$ \\
\hline Belgia & BANT & (procedura $\mathrm{w}$ toku) & BELCERT & (procedura $\mathrm{w}$ toku) \\
\hline Francja & CONFRED & (procedura $\mathrm{w}$ toku) & BELCERT & (procedura $\mathrm{w}$ toku) \\
\hline Wielka Brytania & $\mathrm{PCN}$ & 04.1993 & NACCB & Railways Sektor \\
\hline Włochy & CIC-PND & 25.01 .1994 & SINCERT & CIC-PND \\
\hline Holandia & SKO & 25.06 .95 & $\begin{array}{c}\text { Road Voor de } \\
\text { certificate }\end{array}$ & $\begin{array}{c}\text { Zintegrowany Sektor } \\
\text { kolejowy w zakresie } \\
\text { przedsiębiorstwa }\end{array}$ \\
\hline
\end{tabular}

SKO- Szwajcarska Organizacja Kadrowa

Instytucje akredytujące

TGA- Stowarzyszenie d.s. Akredytacji Sp. z o.o.

BELCERT- Belgijskie Stowarzyszenie Akredytacji

COFRAC- Francuski Komitet Akredytacji dla Certyfikowanych Pojazdów

NACCB- Rada Narodowa Akredytacji dla Certyfikowanych Pojazdów

SICERT- Narodowy Urząd ds. Akredytacji dla Certyfikowanych Pojazdów

Karta UIC 960 [8] uwzględnia trzy stopnie kwalifikacji dla pracowników, wykonujących badania nieniszczące:

- pracownik stopnia 1, który posiada kwalifikacje do przeprowadzenia badań nieniszczących według pisemnych wskazówek, w których jest ustalony sposób postępowania dla badań oraz regulacje, które należy przeprowadzić jak również kryteria klasyfikacyjne wyrażone w sposób jak przy podaniu danych o nieregularnościach zastosowanej metody

- pracownik stopnia 2, który jest wykwalifikowany do przeprowadzenia badań i kontroli tych prac, które zostały powierzone pracownikowi stopnia 1 i któremu on świadczy pomoc w problemach interpretacyjnych otrzymanych wyników badań; pracownik ten musi posiadać kwalifikacje do przygotowania i opracowania pisemnych instrukcji $\mathrm{w}$ zależności od poleceń, które zostały mu wydane

- pracownik stopnia 3, który jest wykwalifikowany do określenia metody i do ustalenia metod zastosowania jak również metod badawczych, które należy zastosować w zależności od przepisów naprawczych i rzeczywistych warunków pracy; pracownik musi dalej wykazywać zdolności do weryfikacji przygotowanych instrukcji przez pracowników stopnia 2 i do kontroli ich właściwego zastosowania. Pracownik stopnia 3 może być powołany do kontroli badań kwalifikacyjnych w centrum badawczym.

Badania kwalifikacyjne odbywają się w centrum badawczym, które może być dopuszczone przez niezależną instytucję certyfikującą lub autoryzowany komitet sektora kolejowego. Badania kwalifikacyjne sa prowadzone przez pracowników stopnia 3, którzy są wyznaczani przez ww. instytucje. Badania te przeprowadza się zgodnie z przepisami normy europejskiej EN 473 [5] wg sporządzonego na piśmie porządku metodologicznego, który został dopuszczony przez ww. wymienioną niezależną instytucję.

Kandydaci do kwalifikowania muszą być przeszkoleni w zasadniczych podstawach stosowanych metod pomiarowych jak również metod zastosowania w odpowiednim zakresie częściowym przy wprowadzeniu do techniki kolejowej, przy czym czas szkolenia pozostawia się do uznania przedsiębiorstwu kolejowemu. Dla pracowników stopnia 1 i 2 wymagane czasy szkolenia dla różnych metod badawczych są przedstawione w tabeli 7.

Dla pracowników stopnia 3, którzy dysponują fachową wiedzą naukową i inżynierską ustala się dodatkowe wykształcenie do przeprowadzenia badań nieniszczących i wytycznych normy europejskiej EN-473 [5]. Badania kwalifikacyjne dla pracowników stopnia 1 i 2 składają się z trzech części:

- ogólnej ankiety do podstawowych zasad odpowiedniej metody badawczej

- $\quad$ specjalnej ankiety do metody badawczej oraz odpowiednio zastosowanych zakresów częściowych kolejnictwa

- praktycznej kontroli o wybranej metodzie badawczej, która jest reprezentatywna dla metod i badań, które są rzeczywiście praktykowane w odpowiednim zakresie częściowym kolejnictwa i odbywa się na podstawie bezbłędnych, wzorcowanych części lub podzespołów. 
Minimalne czasy szkolenia dla pracowników stopnia 1 i 2 w godzinach wg karty UIC 960 [8] Tabela 7

\begin{tabular}{|c|c|c|c|}
\hline \multirow{2}{*}{$\begin{array}{c}\text { Metoda badań } \\
\text { nieniszczących }\end{array}$} & Stopień 1 szkolenia & $\begin{array}{c}\text { Sako dołączenie do } \\
\text { szkolenia stopnia 1 }\end{array}$ & $\begin{array}{c}\text { Bezpośrednie } \\
\text { przystąpienie do } \\
\text { szkolenia }\end{array}$ \\
\cline { 3 - 4 } & & 80 & 160 \\
\hline $\begin{array}{c}\text { badań ultradźwiękowych } \\
(\mathrm{UT})\end{array}$ & 80 & 24 & 48 \\
\hline $\begin{array}{c}\text { badań magnetycznych } \\
(\mathrm{MT})\end{array}$ & 40 & 14 & 80 \\
\hline $\begin{array}{c}\text { badań prądami wirowymi } \\
(\mathrm{ET})\end{array}$ & 16 & 24 & 40 \\
\hline $\begin{array}{c}\text { badań penetracyjnych } \\
(\mathrm{PT})\end{array}$ & czas zastrzeżony & \multicolumn{2}{c|}{ czas zastrzeżony } \\
\hline badań optycznych (VT) & & & 2 \\
\hline
\end{tabular}

\section{Wnioski}

Na podstawie przeprowadzonych analiz można stwierdzić, że dla osi zestawów kołowych tocznych oraz trakcyjnych można prognozować ich stan techniczny. Do tego celu służą postawy teoretyczne, do której można zaliczyć mechanikę pękania oraz metody doświadczalne. $\mathrm{Z}$ opisanych metod teoretycznodoświadczalnych wynika, że określanie wieku zestawów kołowych jako kryterium kwalifikacji jest pozbawione sensu technicznego. Bardziej obiecujące są techniki prognozowania oparte na ustaleniu rzeczywistej granicy zmęczenia opartej o realne siły występujące w eksploatacji [1]. Jednym z kryteriów kwalifikacji osi może być przebieg kilometrowy, który w przypadku pojazdów trakcyjnych musi być powiązany z rzeczywistym zespołem obciążeń, działającym na oś zestawu kołowego. Stąd wynika konieczność „rejestracji rzeczywistego widma obciążeń”, o które powinien zabiegać właściciel pojazdu oraz infrastruktury. Jednym $\mathrm{z}$ istotnych parametrów decydującym o kwalifikacji osi zestawów kołowych do eksploatacji jest stosowanie badań nieniszczących. Ważna jest częstotliwość wykonywanych badań kontrolnych, aby można było zawczasu wykryć pęknięcie zmęczeniowe w osi zestawu kołowego. Poważnym wsparciem dla zwiększenia żywotności osi zestawów kołowych jest norma europejska PN-EN 13261:2009 [11]. Przepisy tej normy w zakresie wytwarzania, procesów kontrolnych i odbiorczych stanowią istotny postęp w stosunku do dotychczas obowiązującej karty UIC 811-1 [7]. Podniesienie jakości wyprodukowanych zestawów kołowych, a w szczególności poprawienie zabezpieczenia przed korozją przez zastosowanie odpowiedniej jakości powłok malarskich przyczynia się niewątpliwie do zwiększenia żywotności osi zestawów kołowych [3]. Zgodnie z obecnymi oczekiwaniami ze strony użytkowników taboru kolejowego producent powłok malarskich powinien udzielić gwarancji na okres 5 do 8miu lat. Wynika to $z$ dotychczasowych negatywnych doświadczeń z eksploatacji, gdzie stwierdzono że skuteczność powłoki malarskiej jest szacowana na okres co najwyżej 2 do 3 lat.

\section{Literatura}

[1] Hasslinger H.: Lastannahmen für RadsatzwellenBestandsanalyse. Eisenbahntechnische Rundsachau. $\mathrm{Nr}$ 12, 12.2009.

[2] Liedgens K.: Inspektionskonzept für Radsatzwellen bei der Hamburger Hochbahn. Eisenbahningenieur. $\mathrm{Nr} 3 / 2010$.

[3] Murawa F., Winkler M..: Randschichtbehandelte Radsatzwellen. Eisenbahningenieur Nr.7/2007.

[4] Richard A., Sander M., Wirxel M., Lebehahn J.: Ermittlung von Inspektionsinterwallen mittels Risswachstumsuntersuchungen. Eisenbahningenieur. Luty 2010

[5] EN 473: Kwalifikacja i certyfikacja personelu do badań nieniszczacych. Ogólne zasady. Marzec 1993.

[6] EN 45013: Ogólne wymagania dotyczace opinii $i$ akredytacji placówek certyfikujacych (ISO/IEC Tom 61:1996).1998.

[7] Karta UIC 811-1: Warunki techniczne na dostawe osi zestawów kołowych dla pojazdów trakcyjnych $i$ wagonów

[8] Karta UIC 960: Kwalifikacja i certyfikacja personelu odpowiedzialnego za prowadzenie badań nieniszczacych elementów zespotów pojazdów szynowych w procesie ich utrzymania.2-gie wydanie z grudnia 2001.

[9] PN-EN 13103:2009: Kolejnictwo. Zestawy kolowe i wózki. Osie zestawów kołowych tocznych. Zasady konstrukcji.

[10] PN-EN 13104:2009: Kolejnictwo. Zestawy kołowe i wózki. Osie zestawów kołowych napędnych. Zasady konstrukcji.

[11] PN-EN 13261:2009: Kolejnictwo. Zestawy kolowe i wózki. Osie. Wymagania dotyczqce wyrobu.

[12] Raport ORE/ERRI B136/Rp.11/D. Zestawy kolowe z nasadzanymi tożyskami tocznymi. Konstrukcja, utrzymanie i standaryzacja. Obliczenie osi zestawów kolowych dla wagonów towarowych $i$ osobowych. Utrecht, kwiecień 1979.

[13] OR-9666: „Diagnostyka układów biegowych pojazdów tocznych i trakcyjnych." Wrzesień 2010. 